\title{
Potential toxicity of aluminum and fluoride on some biochemical aspects of male rat's offspring
}

Amal A. Kinawy (D

\begin{abstract}
Background: This work was designed to evaluate the potential hazards of sodium fluoride (NaF) and aluminum chloride $\left(\mathrm{AlCl}_{3}\right)$ given separately or in conjugation throughout the prenatal and up to weaning time or till the postnatal 70th day. The levels of the following parameters were then assessed; vitamin C (ascorbic acid), glutathione (GSH) and oxidized glutathione (GSSH), malondialdehyde (MDA), total protein, albumin, total calcium, ionized calcium, creatinine, urea, uric acid, and bilirubin. In addition, the activities of alanine aminotransferase (ALT) and aspartate aminotransferase (AST) were determined. In this study, female pregnant rats were allocated into four groups. The first received the drinking deionized water and served as a normal group, the second was given a daily dose of $\mathrm{NaF}$ $(0.15 \mathrm{~g} / \mathrm{L})$ dissolved in deionized water from day 6 of gestation till the end of the weaning period, and the third was given a daily dose of $\mathrm{AlCl}_{3}(500 \mathrm{mg} / \mathrm{L})$ for the same period of time. The fourth group was given drinking water containing combined doses of $\mathrm{NaF}+\mathrm{AlCl}_{3}$ for a similar length of time. Each group was further divided into two subgroups; the first continued to be treated with the same pollutants in drinking deionized water at the same dose level until the age of 70 days, whereas the second group was supplied with pure deionized water free from the intoxicating substances for the same period of time.

Results: The results revealed that either $\mathrm{NaF}$ or $\mathrm{AlCl}_{3}$ given separately or in conjunction with each other abated the quenching effects of the antioxidant system and induced oxidative stress and several perturbations in the aforementioned parameters. The metals caused significant increase in the levels of urea, uric acid, creatinine, and activities of ALT and AST activities, whereas the levels of total and ionized calcium in serum and the concentration of vitamin C, GSH, and GSH/GSSG ratio in hepatic tissues were significantly decreased and the levels of MDA were markedly increased in the liver as a response to the studied metals.
\end{abstract}

Conclusion: Based on the present results, the exposure to sodium fluoride or aluminum chloride induced profound perturbation in the liver and kidney functions.

Keywords: Fluoride, Aluminum, Vitamin C, Reduced glutathione, Oxidized glutathione, Lipid peroxidation, Liver and kidney functions

\section{Background}

Chronic exposure to fluoride and aluminum or aluminum/ fluoride leads to accumulation of both elements in the lung, brain, gastric endocrine glands, kidney, and liver. This is concomitant with metabolic alternation and tissues damage; fluoride is an essential trace element, present in air, water, and food that may produce chronic alterations in

Correspondence: aa_behphys2002@yahoo.com

Biology Department, Faculty of Science, Taif University, Taif 5700, Kingdom of Saudi Arabia human health when they are exposed to it (Kinawy \& Al-Eidan, 2018; Kinawy \& Ezzat, 2013; Tan, Liu, Zhang, $\mathrm{Liu}, \mathrm{Lu}, \mathrm{Yu}, \mathrm{Tu}$, \& Cui, 2011). On the other hand, either aluminum or sodium fluoride (NaF) toxicity causes severe imbalances in the oxidant-antioxidant system and as consequences generate the reactive oxygen species (ROS) that contain unpaired electrons; these are highly reactive and can cause damage to the nucleic acid, lipids, proteins, and carbohydrates (Benyettou, Kharoubi, Hallal, Benyettou, Tair, Belmokhtar, Aoues, \& Ozaslan M, 2017; Kinawy \& Ezzat, 2013), Oxidative stress is developed when there is an

\section{Springer Open}

(c) The Author(s). 2019 Open Access This article is distributed under the terms of the Creative Commons Attribution 4.0 International License (http://creativecommons.org/licenses/by/4.0/), which permits unrestricted use, distribution, and reproduction in any medium, provided you give appropriate credit to the original author(s) and the source, provide a link to the Creative Commons license, and indicate if changes were made. 
increase in the production of free-radical derivatives from oxygen and may serve as common mediators of neurotoxicity in response to fluoride and aluminum toxicity (Kaur, Bijarnia, \& Nehru, 2009). Previous literature hypothesize that sodium fluoride is capable to penetrate the soft tissues such as liver by simple diffusion and induce several perturbations in the metabolic homeostasis and liver detoxification capacity, and subsequently initiate reactive oxygen species and generation oxidative stress in the liver and kidneys tissues (Chattopadhyay, Podder, Agarwal, \& Bhattacharya, 2011; Dabrowaska, Letko, \& Balunowska, 2006; Zhang, Zhou, Wang, Wang, Song, Liu, \& Xi, 2014). In addition, elevation of the liver enzymes may lead to cellular degeneration of hepatic cells. The liver is considered the main organ which is responsible for metabolism and detoxication. In addition, $\mathrm{NaF}$ induce several perturbations in antioxidants defense system with higher rate of lipid peroxidation membrane damage (Anuradha, Kanno, \& Hirano, 2001; Chen, Proestou, Bourbeau, \& Wang, 2000; He \& Chen, 2006; Nabavi, Habtemariam, Jafari, Sureda, \& Nabavi, 2012; Trivedi, Verma, Sangai, \& Chinoy, 2011), that leads to membrane dysfunction and as a consequence increases its permeability to calcium ions influx and mitochondrial injuries. On the other hand, the in-utero exposure to aluminum and fluoride has deleterious irreversible effects of some biochemical and physiological aspects. In this regard, the problem of exposure of the prenatal and early postnatal to aluminum and fluoride are of particular interest because it may have devastating, and probably irreversible impacts on several vital processes. This is likely because the metabolic pathways, biotransformation, elimination mechanisms, gut, liver, neuro-hormonal balances and renal functions, neural development, and particularly brain barrier formation are not fully developed in early stages (Bishop, Morley, Chir, Day, \& Lucas, 1997; Kinawy \& Al-Eidan, 2018; Kinawy \& Ezzat, 2008, 2013; Weaver, Laker, \& Nelson, 1984). In addition to the high affinity of fluoride for aluminum, this complex may occur spontaneously in body fluids. Furthermore, central pathophysiological mechanism may be responsible for much of the toxicity of aluminum and aluminofluoride compounds on the soft tissues (Blaylock, 2012). Vitamin C (ascorbic acid) is a cofactor for several enzymes; in addition, it prevents free radicals and acts as antagonistic to the toxic, mutagenic, and carcinogenic effects of environmental pollutants by stimulating liver detoxifying enzymes (Jan et al., 2015; Kojo, 2000). Consequently, this study was carried out to investigate the impact of aluminum chloride and sodium fluoride given separately or in combination throughout the prenatal and weaning periods or up to day 70 of postnatal stages.

\section{Material and methods \\ Animals}

This study was carried out using adult female waster rats $(180-220 \mathrm{~g})$. The animals were obtained from the animal house of the Institute of Ophthalmic Disease Research. All animals were maintained under a controlled environment at $20{ }^{\circ} \mathrm{C}$ with $12 \mathrm{~h}$ dark/light cycle and $50-70 \%$ humidity. Pregnant rats and the neonates were fed milk and bread and provided with water ad libitum.

\section{Breeding program}

Each female was mated with a proven male of the same strain in the separate cage following the traditional commercial system. Vaginal smears were taken to detect the presence of true estrus and sperm to confirm pregnancy according to the protocol described by Ozbilgin, Boz, Inan, and Vatansever (2012).

\section{Experimental design}

This experiment was conducted to investigate the effects of the hazards of sodium fluoride and aluminum chloride given separately or in combination through the prenatal life and up after weaning or up to 70 days of postnatal stages. Eighty pregnant female rats were randomly divided into 4 equal groups. The first group represent the control group that received the pure drinking deionized, the second, ingested $\mathrm{NaF} 0.15 \mathrm{~g} / \mathrm{L}$ ( $\mathrm{He} \&$ Chen, 2006) dissolved in pure deionized water, the third exposed to $0.5 \mathrm{~g} / \mathrm{L}$ aluminum chloride $\left(\mathrm{AlCl}_{3}\right)$ (Fulton \& Jeffery, 1990) dissolved in pure deionized water, and the fourth administered $\mathrm{NaF}$ plus $\mathrm{AlCl}_{3}$ dissolved in pure deionized water; after parturition, the mothers continued to have the same polluted substances and the pups were exposed to polluted substance through breastfeeding and left for natural maternal care during the first period of their development. Then after just the weaning stage, only the male rats were used and each group was divided into two subgroups; the first one supplied with pure ionized water and the other subgroups continued to have a daily the same dose level of polluting substances $\left(\mathrm{NaF} 0.15 \mathrm{~g} / \mathrm{L}, 0.5 \mathrm{~g} / \mathrm{L} \mathrm{AlCl}_{3}\right.$ separately and $\mathrm{NaF}$ $+\mathrm{AlCl}_{3}$ dissolved in drinking deionized water respectively) until day 70 of postnatal periods. Thus, the experimental groups were:

Normal group (NPP-G): normal (N) offspring given deionized $\mathrm{H}_{2} \mathrm{O}$ throughout the pre- $(\mathrm{P})$ and postnatal (P) periods until 70 days old.

FPP-G: offspring exposed to sodium fluoride (F) throughout pre- (P) and postnatal periods until 70 days old.

FP-G: offspring exposed to $\mathrm{NaF}$ (F) throughout the prenatal $(\mathrm{P})$ period only. 
APP-G: offspring exposed to $\mathrm{AlCl}_{3}$ (A) throughout pre- $(\mathrm{P})$ and postnatal $(\mathrm{P})$ periods until 70 days old. AP-G: offspring exposed to $\mathrm{AlCl}_{3}$ (A) throughout the prenatal $(\mathrm{P})$ period only.

FAPP: offspring exposed to $\mathrm{NaF}+\mathrm{AlCl}_{3}$ (FA) throughout pre- $(\mathrm{P})$ and postnatal $(\mathrm{P})$ periods until 70 days old.

FAP: offspring exposed to $\mathrm{NaF}+\mathrm{AlCl}_{3}$ (FA)

throughout the prenatal $(\mathrm{P})$ period only.

The rats were slightly anesthetized with pentobarbital (30 mg/kg, i.p. injection), and blood was collected from the abdominal dorsal aorta. Blood was collected and serum was separated for the biochemical and physiological analyses. Determination of serum levels of total protein, urea, and albumin was performed by using a commercial diamond diagnostics kit and determined by the colorimetric method according to the method of Young (2001).

Serum creatinine, alanine aminotransferase (ALT/ GPT), aspartate aminotransferase (AST), and calcium were determined by bio-systems kits according to the method of Young (1997); and free calcium was calculated according to the following equation:

$$
\text { Ionized calcium }=\frac{6 \times \text { total calcium }-K / 3}{K+6}
$$

where:

$$
K=(0.19 \times \text { T.protein })+\text { albumin }
$$

Serum concentration of urea was determined by the method of Patton and Crouch (1977). Serum bilirubin was determined by Sigma-Aldrich (Merck) by colorimetric methods by Bulmer, Verkade, and Wagner (2012).

HPLC determination of the malondialdehyde (MDA) as lipid peroxidation marker and ascorbic acid concentrations: weighing and homogenization of the tissue: $0.1 \mathrm{~g}$ of liver tissues was freezing in liquid hydrogen, was homogenized in $1 \mathrm{ml} 0.1 \%$ trichloroacetic acid for precipitation of protein and then was homogenized with $10 \%$ perchloric acids and centrifuged at $5000 \mathrm{rpm}$ for 5 min then the supernatant was injected to HPLC devices. The mobile phase was contained from $30 \mathrm{mmol}$ $\mathrm{KH}_{2} \mathrm{PO}_{4}$ and methyl alcohol with $82.5-17.5 \% \mathrm{H}_{3} \mathrm{PO}_{4}$ at $\mathrm{pH}=4.0$ was used as mobile phase; the flow rate of the mobile phase was $1 \mathrm{ml} / \mathrm{min}$. ODS4 HPLC column (150 $\mathrm{mm} \times 4.6$ column) was used. The resulting chromatogram identified each malonaldehyde and ascorbic acid position and concentration from the sample as compared to that of the standard, and finally, the determination of the content of each malonaldehyde and ascorbic acid as nmol/g per gram tissues (Karatepe, 2004).

Measurement of oxidized and reduced glutathione of liver was done by weighing and homogenization of $0.1 \mathrm{~g}$ of iced $\mathrm{KCl}$ followed immediately by deproteinization and acidification with sulfosalicylic acid. A liver tissue was eluted by using $0.0025 \mathrm{M}$ sodium phosphate buffer at $\mathrm{pH} 3.50$ (with $0.005 \mathrm{M}$ tetrabutylammonium phosphate (Waters, Milford, MA) and 13\% methanol). The homogenate was spun at $5000 \mathrm{rpm}$ for $10 \mathrm{~min}$ and the supernatant was used for glutathione (GSH) and oxidized glutathione (GSSH) determination immediately extracted from the trace elements and lipids by the use of solid phase $30-\mathrm{cm} \times 3.9-\mathrm{mm} \mathrm{C}-18 \mathrm{mu}$ Bondapak column and detected with an ultraviolet (UV) detector at $190 \mathrm{~nm}$. Flow rate: $1 \mathrm{ml} / \mathrm{min}$ (Jayatilleke \& Shaw, 1993).

\section{Statistical analysis}

Kolmogorov-Smirnov test indicated that the data were normally distributed, and therefore the parametric statistical analyses were applied. One-way analysis of variance (ANOVA) was applied to analyze the effect of treatments on the studied parameters of male rat offspring, then followed by Duncan's test of homogeneity (post-ANOVA hoc) to compare between all variables at significant level $\alpha=0.05(P<0.05)$. Statistical analyses were done by the aid of the IBM Statistical Package for the Social Sciences (SPSS) version 24.

\section{Results}

The group that was given $\mathrm{NaF}$ and $\mathrm{AlCl}_{3}$ separately or in combination throughout the prenatal and weaning period followed by the same treatment up to day 70 and had a significant decrease in the levels of the protein in comparison with the normal group. On the other hand, the groups exposed to the pollutants from day 6 of gestation up to just after the weaning stage did not reveal any significant change in comparison with the normal group that was lower than each one group administered the polluted substances. The group that was given the combination of $\mathrm{NaF}+\mathrm{AlCl}_{3}$ exhibited lower level than the group administered the polluted substances during the prenatal and weaning stages. Albumin was significantly reduced in the group exposed to the combination of $\mathrm{NaF}+\mathrm{AlCl}_{3}$ than the control and aluminum groups. The level of uric acid was significantly increased in the groups given $\mathrm{NaF}, \mathrm{AlCl}_{3}$ alone, or in combination until the age of 70 days when compared with the control values, and these groups approached each other, and higher than the group exposed to $\mathrm{NaF}+\mathrm{H}_{2} \mathrm{O}, \mathrm{AlCl}_{3}+$ $\mathrm{H}_{2} \mathrm{O}$, and $\mathrm{NaF}+\mathrm{AlCl}_{3}+\mathrm{H}_{2} \mathrm{O}$. Urea level was elevated in all treated groups in comparison with the normal group. The group administered $\mathrm{NaF}, \mathrm{AlCl}_{3}$ separately, or in combination until the age of 70 days was significantly higher than the groups given the polluted substances for a short time from the prenatal to weaning stages (Table 1). 
Table 1 The levels of total proteins, albumin, uric acid, and urea in the serum of offspring rats exposed to $\mathrm{NaF}$ or $\mathrm{AlCl}_{3}$ alone and in combination through the pre- or/and postnatal stages until 70 days

\begin{tabular}{lllll}
\hline Experimental groups & Total proteins $(\mathrm{g} / \mathrm{dl})$ & Albumin $(\mathrm{g} / \mathrm{dl})$ & Uric acid $(\mathrm{mg} / \mathrm{dl})$ & Urea $(\mathrm{mg} / \mathrm{dl})$ \\
\hline N-G & $5.35 \pm 0.1$ & $3.36 \pm 0.05$ & $2.62 \pm 0.08$ & $9.36 \pm 0.13$ \\
FPP-G & $4.9 \pm 0.12^{\mathrm{a}}$ & $3.17 \pm 0.1$ & $3.11 \pm 0.07^{\mathrm{a}}$ & $11.16 \pm 0.35^{\mathrm{a}}$ \\
FP-G & $5.4 \pm 0.23^{\mathrm{b}}$ & $3.2 \pm 0.065$ & $2.34 \pm 0.08^{\mathrm{b}}$ & $10.05 \pm 0.2^{\mathrm{abc}}$ \\
APP-G & $4.9 \pm 0.09^{\mathrm{ac}}$ & $3.25 \pm 0.05$ & $3.27 \pm 0.07^{\mathrm{ac}}$ & $11.99 \pm 0.09^{\mathrm{abc}}$ \\
AP-G & $5.25 \pm 0.07^{\mathrm{db}}$ & $3.2 \pm 0.03$ & $2.45 \pm 0.06^{\mathrm{bd}}$ & $9.89 \pm 0.12^{\mathrm{abd}}$ \\
FAPP-G & $4.7 \pm 0.08^{\mathrm{ace}}$ & $3.02 \pm 0.05^{\mathrm{ad}}$ & $3.37 \pm 0.21^{\mathrm{ace}}$ & $12.3 \pm 0.19^{\mathrm{abce}}$ \\
FAP-G & $5.6 \pm 0.1^{\text {bdef }}$ & $3.2 \pm 0.09$ & $2.65 \pm 0.06^{\mathrm{abcdf}}$ & $9.92 \pm 0.08^{\mathrm{abdf}}$ \\
\hline
\end{tabular}

Values are expressed as a mean of eight offspring \pm SEM

$\mathrm{N}$ : normal offspring given deionized $\mathrm{H}_{2} \mathrm{O}$ throughout the pre- and postnatal periods until 70 days old

FPP: offspring exposed to $\mathrm{NaF}$ throughout pre- and postnatal periods until 70 days old

FP: offspring exposed to NaF throughout the prenatal and up to the end of weaning stages

APP: offspring exposed to $\mathrm{AlCl}_{3}$ throughout pre- and postnatal periods until 70 days old

AP: offspring exposed to $\mathrm{AlCl}_{3}$ throughout the prenatal and up to the end of weaning stages

FAPP: offspring exposed to $\mathrm{NaF}+\mathrm{AlCl}_{3}$ throughout pre- and postnatal periods until 70 days old

FAP: offspring exposed to $\mathrm{NaF}+\mathrm{AlCl}_{3}$ throughout the prenatal and up to the end weaning stages

$a, b, c, d, e, f:$ Significant difference in comparison with the corresponding N, FPP, FP, APP, AP, FAPP, and FAP groups at $a=0.05(P<0.05)$

Table 2 shows that the levels of ALT had a significant increase in all treated groups as compared with the control values. On other hand, both groups exposed to $\mathrm{NaF}$ $+\mathrm{AlCl}_{3}$ and $\mathrm{NaF}+\mathrm{AlCl}_{3}+\mathrm{H}_{2} \mathrm{O}$ exhibited a higher level than that in the other groups. The level of creatinine values in the group exposed to $\mathrm{NaF}$ individually or in combination with aluminum were significantly higher than in the corresponding control group; moreover, the group exposed to the aluminum and sodium fluoride exceeded significantly the other each one group; further, the groups exposed to $\mathrm{AlCl}_{3}$ and $\mathrm{AlCl}_{3}+\mathrm{H}_{2} \mathrm{O}$-treated groups had no significant change in comparison with control values, and these groups had lower values than either $\mathrm{NaF}$ or $\mathrm{NaF}+\mathrm{AlCl}_{3}+\mathrm{H}_{2} \mathrm{O}$ groups.

The offspring in all groups exposed to $\mathrm{NaF}, \mathrm{AlCl}_{3}$ alone, or in combination throughout the prenatal and weaning periods followed by the same treatment up to day 70 had a significant decrease in the level of the vitamin $\mathrm{C}$ when compared with the corresponding normal, $\mathrm{NaF}+\mathrm{H}_{2} \mathrm{O}, \mathrm{AlCl}_{3}+\mathrm{H}_{2} \mathrm{O}$, and $\mathrm{NaF}+\mathrm{AlCl}_{3}+\mathrm{H}_{2} \mathrm{O}$, but the groups administered $\mathrm{NaF}+\mathrm{H}_{2} \mathrm{O}, \mathrm{AlCl}_{3}+\mathrm{H}_{2} \mathrm{O}$, and
$\mathrm{NaF}+\mathrm{AlCl}_{3}+\mathrm{H}_{2} \mathrm{O}$ did not reveal significant changes when compared with the normal. Lipid peroxide was higher in all tested groups than the normal group, except $\mathrm{AlCl}_{3}+\mathrm{H}_{2} \mathrm{O}$ group which had no significant change in comparison with the normal values, however is lower than all treated groups. Moreover, the combination of $\mathrm{AlCl}_{3}$ and $\mathrm{NaF}$ exhibited lower levels than all groups exposed through the prenatal and weaning stages. Reduced glutathione was reduced in both groups exposed to $\mathrm{NaF}$ or $\mathrm{NaF}+\mathrm{AlCl}_{3}$ in comparison with the normal.

Each group ingested $\mathrm{AlCl}_{3}$ alone did not reveal any significant change from the normal values. Most of studied parameters in groups given $\mathrm{NaF}+\mathrm{AlCl}_{3}$ were significantly higher than all groups exposed to $\mathrm{AlCl}_{3}$ alone. The level of oxidized glutathione was significantly increased in all groups that administered polluted substances than the normal group. Moreover, the group that was given the combination of $\mathrm{NaF}+\mathrm{AlCl}_{3}$ exhibited a higher value than $\mathrm{NaF}, \mathrm{NaF}+\mathrm{H}_{2} \mathrm{O}, \mathrm{AlCl}_{3}+\mathrm{H}_{2} \mathrm{O}$, and $\mathrm{NaF}+\mathrm{AlCl}_{3}+\mathrm{H}_{2} \mathrm{O}$ exposed groups, but approached to

Table 2 Activities of alanine aminotransferase (ALT) and aspartate aminotransferase (AST), the levels of creatinine and bilirubin in serum of offspring rats exposed to $\mathrm{NaF}$ or $\mathrm{AlCl}_{3}$ alone and in combination through the pre- or/and postnatal stages until 70 days

\begin{tabular}{lllll}
\hline Experimental group & ALT & AST & Creatinine & Bilirubin \\
$\mathrm{mg} / \mathrm{dl}$ & $\mathrm{U} / \mathrm{L}$ & $0.64 \pm 0.015$ & $1.145 \pm 0.004$ \\
\hline N-G & $32.87 \pm 2.3$ & $147 \pm 2.5$ & $0.76 \pm 0.05^{\mathrm{a}}$ & $1.162 \pm 0.0025$ \\
FPP-G & $41.62 \pm 1.83^{\mathrm{a}}$ & $180 \pm 2.07^{\mathrm{a}}$ & $0.68 \pm 0.005$ & $1.155 \pm 0.004$ \\
FP-G & $37.87 \pm 1.89^{\mathrm{a}}$ & $146 \pm 1.7^{\mathrm{b}}$ & $0.65 \pm 0.013^{\mathrm{b}}$ & $1.151 \pm 0.023$ \\
APP-G & $39.87 \pm 0.69^{\mathrm{a}}$ & $173 \pm 2.85^{\mathrm{ac}}$ & $0.566 \pm 0.017^{\mathrm{bc}}$ & $1.159 \pm 0.008$ \\
AP-G & $38.19 \pm 0.6^{\mathrm{a}}$ & $150 \pm 2.48^{\mathrm{bd}}$ & $0.92 \pm 0.06^{\text {abcde }}$ & $1.16 \pm 0.023$ \\
FAPP-G & $48.45 \pm 2.2^{\text {abcde }}$ & $180 \pm 3.78^{\text {acde }}$ & $0.75 \pm 0.02^{\text {adef }}$ & $1.157 \pm 0.055$ \\
FAP-G & $47.25 \pm 2.5^{\text {abcde }}$ & $154 \pm 2.5^{\text {abcdf }}$ & & \\
\hline
\end{tabular}

Caption description and details as in Table 1 
Table 3 The levels of vitamin C, malondialdehyde (MDA), glutathione (GSH), and glutathione disulphide (GSSG) and the ratio of GSH to GSSG in the liver of offspring rats exposed to $\mathrm{NaF}$ or $\mathrm{AlCl}_{3}$ alone and in combination through the pre- or/and postnatal stages until 70 days

\begin{tabular}{llllll}
\hline Experimental groups & Vitamin C $(\mu \mathrm{mol} / \mathrm{g})$ & MDA $(\mathrm{nmol} / \mathrm{g})$ & GSH $(\mu \mathrm{mol} / \mathrm{g})$ & GSSG $(\mu \mathrm{mol} / \mathrm{g})$ & GSH/GSSG \\
\hline N-G & $10.64 \pm 0.065$ & $57.37 \pm 1.8$ & $8.9 \pm 0.23$ & $60.17 \pm 1.6$ & $0.149 \pm 0.006$ \\
FPP-G & $9.34 \pm 0.18^{\mathrm{a}}$ & $72.87 \pm 2.5^{\mathrm{a}}$ & $7.51 \pm 0.24^{\mathrm{a}}$ & $65.7 \pm 0.75^{\mathrm{a}}$ & $0.114 \pm 0.004^{\mathrm{a}}$ \\
FP-G & $10.36 \pm 0.063^{\mathrm{b}}$ & $67.85 \pm 1.3^{\mathrm{a}}$ & $7.96 \pm 0.215^{\mathrm{a}}$ & $64.92 \pm 1.12^{\mathrm{a}}$ & $0.123 \pm 0.0035^{\mathrm{a}}$ \\
APP-G & $9.40 \pm 0.13^{\mathrm{ac}}$ & $72.62 \pm 2.3^{\mathrm{a}}$ & $8.58 \pm 0.241^{\mathrm{b}}$ & $71.63 \pm 1.42^{\mathrm{ab}}$ & $0.12 \pm 0.005^{\mathrm{a}}$ \\
AP-G & $10.52 \pm 0.34^{\mathrm{bd}}$ & $61.66 \pm 1.8^{\mathrm{bdc}}$ & $8.83 \pm 0.40^{\mathrm{bc}}$ & $66.94 \pm 0.578^{\mathrm{ad}}$ & $0.132 \pm 0.006^{\mathrm{ab}}$ \\
FAPP-G & $9.35 \pm 0.34^{\mathrm{ace}}$ & $77.24 \pm 1.73^{\mathrm{ace}}$ & $7.29 \pm 0.27^{\mathrm{ade}}$ & $73.67 \pm 1.135^{\mathrm{ab}} \mathrm{ce}$ & $0.099 \pm 0.0041^{\mathrm{abcde}}$ \\
FAP-G & $10.41 \pm 0.24^{\mathrm{bdf}}$ & $69.34 \pm 1.1^{\text {aef }}$ & $7.98 \pm 0.23^{\mathrm{ae}}$ & $66.64 \pm 0.481^{\mathrm{adf}}$ & $0.125 \pm 0.0058^{\mathrm{af}}$ \\
\hline
\end{tabular}

Caption description and details as in Table 1

a long-term exposed group. The group exposed to $\mathrm{AlCl}_{3}$ alone exceeded the group given $\mathrm{NaF}$ alone, $\mathrm{AlCl}_{3}+$ $\mathrm{H}_{2} \mathrm{O}$, and $\mathrm{NaF}+\mathrm{AlCl}_{3}+\mathrm{H}_{2} \mathrm{O}$-treated groups. The $\mathrm{GSH} /$ GSSH ratio was significantly increased in tested groups as compared to the control group; on the other hand, the group that was given the combination of $\mathrm{NaF}+$ $\mathrm{AlCl}_{3}$ had a significantly higher level than the other treated groups. The level of bilirubin was not significantly different when the comparison was made with the other treated group (Table 3).

Total calcium and ionized calcium levels in $\mathrm{NaF}, \mathrm{NaF}$ $+\mathrm{AlCl}_{3}$, and $\mathrm{NaF}+\mathrm{AlCl}_{3}+\mathrm{H}_{2} \mathrm{O}$-treated groups were significantly lower than the normal values, and both groups exposed to sodium fluoride and aluminum chloride in combination were significantly lower than $\mathrm{AlCl}_{3}$, $\mathrm{NaF}+\mathrm{H}_{2} \mathrm{O}, \mathrm{AlCl}_{3}$, and $\mathrm{AlCl}_{3}+\mathrm{H}_{2} \mathrm{O}$. Either $\mathrm{AlCl}_{3}$ or $\mathrm{AlCl}_{3}+\mathrm{H}_{2} \mathrm{O}$ had no significant change in comparison with the control group and between each one group, but the values of these groups had a significant increase in comparison with the NaF group (Table 4).

\section{Discussion}

The present results revealed that the offspring that received sodium fluoride, aluminum chloride, individually

Table 4 Levels of the total and ionized calcium $(\mathrm{g} / \mathrm{dl})$ in the serum of offspring rats exposed to $\mathrm{NaF}$ or $\mathrm{AlCl}_{3}$ alone and in combination through the pre- or/and postnatal stages until 70 days

\begin{tabular}{lll}
\hline Experimental groups & Total calcium & lonized calcium \\
\hline N-G (6) & $10.64 \pm 0.24$ & $6.33 \pm 0.50$ \\
FPP-G (7) & $9.07 \pm 0.36^{\mathrm{a}}$ & $4.7 \pm 0.064^{\mathrm{a}}$ \\
FP-G (5) & $11.45 \pm 0.15^{\mathrm{ab}}$ & $6.36 \pm 0.11^{\mathrm{b}}$ \\
APP-G (5) & $10.25 \pm 0.25^{\mathrm{bc}}$ & $5.75 \pm 0.20^{\mathrm{b}}$ \\
AP-G (5) & $10.9 \pm 0.71^{\mathrm{b}}$ & $6.15 \pm 0.38^{\mathrm{b}}$ \\
FAPP-G (5) & $8.7 \pm 0.26^{\text {acde }}$ & $4.78 \pm 0.19^{\text {acde }}$ \\
FAP-G (7) & $7.97 \pm 0.08^{\text {abcde }}$ & $4.75 \pm 0.15^{\text {acde }}$ \\
\hline
\end{tabular}

Caption description and details as in Table 1

The numbers between parentheses indicate the number of animals in each experimental group or in combination with each other had significantly elevated lipid peroxides (MDA) levels, which is accompanied by decrease in the ratio of GSH/ GSSH which acts as an indicator of redox potential and antioxidant capacity; furthermore, vitamin $\mathrm{C}$ and both calcium ion and total calcium, as well as total protein were reduced in the groups that ingested the polluted substance throughout the prenatal and postnatal up to the day 70 . In addition, albumin was reduced in the group administered with sodium fluoride plus aluminum. Kidney function is altered and induces an elevation in the creatinine, urea, and uric acid. On the other hand, kidney and liver are highly sensitive to fluoride and aluminum. So, there is an interrelationship between liver function, kidney function, and ingestion of sodium fluoride or aluminum chloride separately or in combination with each other. A lot of theories have been forwarded to explain the mechanism of aluminum or sodium fluoride intoxication including the free radicals and oxidative stress with disturbances in the antioxidant defense system and as consequences disturb cellular nucleotide and induce metabolic disorder (Mailloux, Lemire, \& Apana, 2011; Pawłowska-Goral, Kurzeja, \& Stec, 2013; Viezeliene, Jansen, Rodovicius, Kasauskas, \& Ivanov, 2011). Yildirim et al. (2017, 2018) showed that the chronic exposure to $\mathrm{NaF}$ in the drinking water caused a significant increase in the activities of AST, ALT, and the levels of creatinine and MDA, whereas the levels of GSH in the liver was significantly decreased, and these finding are consistent with our data. They attributed the hepatic and renal functions disturbance to the oxidative stress of these tissues to the response the liberated of the reactive oxygen species (ROS) that caused the degeneration and necrosis of the hepatocytes caused as a result of exposure to NaF. Histologically, they found that $\mathrm{NaF}$ induced oxidative stress to the cardiac muscle, damage of the hepatic, renal, and the cardiac muscle inflammation that causes myocarditis, hyaline degeneration, and leading to Zenker's necrosis. In addition, they attributed the observed hydropic degeneration and necrosis in hepatocytes in the acinar 
region, along with hyperemia in the livers to the chronic fluorosis rats.

It was also reported that $\mathrm{Al}$ or sodium fluoride exposure significantly enhanced liver and kidney damage with concomitant alterations in the enzymatic antioxidant defense status, thus having a serious bearing on the functions and structures of soft tissues (Atmaca, Atmaca, Kanici, \& Anteplioglu, 2014; El-Demerdash, 2004; Hamza, El-Shenawy, \& Ismail, 2015). In addition to the high affinity of fluoride for aluminum, this complex may occur spontaneously in body fluids and magnified the hazards effect. The present results are in agreement with the antecedent studies indicating that aluminum or fluoride caused an elevation in brain MDA accompanied with a decrease in GSH content and SOD activity, in this regard, oxidative damage, reduces the levels of non-enzymatic antioxidant glutathione and disturbs calcium homeostasis (Benyettou et al., 2017; Blaylock, 2012; Kinawy \& Ezzat, 2013; Walton, 2012). On the other hand, both ascorbic acid and GSH are among the most active reducing substances in living tissues that attenuate the reactive oxygen species. It is relevant to mention that the increased enzyme levels ALT and AST activity are considered as an indicator of liver damage and degeneration of the hepatic cells and thus alterations in liver function (Bouaziz et al., 2006; Bouaziz, Amaraa, Essefia, Croute, \& Zeghal, 2010; Eraslan, Kanbur, \& Silici, 2007; Hassan \& Yousef, 2009; Kanbur, Eraslan, Silici, \& Karabacak, 2009; Lu et al., 2017; Xiong et al., 2007; Zhou et al., 2015). With respect to the total protein level, either fluoride or aluminum concentration can lower the serum total protein level; on the other hand, $\mathrm{Al}$ might have interfered with the process of translation at a post-transcriptional level to inhibit the production of protein end products (Chatterjee, Mahapatra, \& Sarkar, 2016; Chinoy \& Memon, 2001; El-Demerdash, 2004; Michael, Barot, \& Chinoy, 1996; Sallam, Nasser, Yousef, El-morsy, \& Mahmoud, 2005; Yousef, 2005). Moreover, total bilirubin was unaffected in all experimental groups. These findings are basically in agreement with the results obtained from similar investigations by Liang et al. (1999). In addition, plasma creatinine concentration is a more sensitive indicator than urea in the first phases of kidney disease; more seriously, the higher level of urea and creatinine in blood might be due to an inability of kidney to excrete the toxic metabolic product (Azab, Albasha, Jbireal, \& Adwas, 2018). In addition, fluoride and aluminum possess a higher capacity to cross cell membranes and easily, inter-visceral organs especially brain, liver, and kidney, as consequences, are burdened with the high levels of these elements (Abdel Aziz \& Masad, 2013; Wasana, Perera, Gunawardena, \& Bandara, 2015).

\section{Conclusions}

In conclusion, the present study explicitly indicates that exposure to sodium fluoride and aluminum chloride during the early stages of life results in several imbalances and disturbances in liver and kidney functions and as a consequence, serious alterations in metabolic homeostasis.

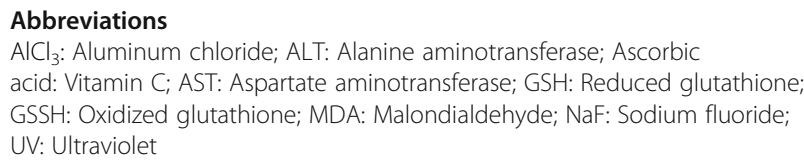

\section{Acknowledgements}

There is no acknowledgment.

Funding

Not funded.

\section{Availability of data and materials}

The data are available from the author.

Authors' contributions

Single author. The author read and approved the final manuscript.

\section{Ethics approval}

Animals were maintained at the College of Science, Taif University animal house, where handling and use of animals were strictly in agreement with the regulations and guidelines set by living Creatures/University of Taif.

\section{Consent for publication}

Not applicable.

\section{Competing interests}

The author declares that she has no competing interests.

\section{Publisher's Note}

Springer Nature remains neutral with regard to jurisdictional claims in published maps and institutional affiliations.

Received: 30 October 2018 Accepted: 22 February 2019

Published online: 12 March 2019

\section{References}

Abdel Aziz, I., \& Masad, A. (2013). Fluoride-induced hematological and biochemical changes in albino rat. The Therapeutic Action of Vitamin C and Olive Oil on Fluoride Effects.ournal of Al Azhar University-Gaza (Natural Sciences), 15, 31-50

Anuradha, C. D., Kanno, S., \& Hirano, S. (2001). Oxidative damage to mitochondria is a preliminary step to caspase-3 activation in fluorideinduced apoptosis in HL-60 cells. Free Radical Biology \& Medicine, 31, 367-373. https://doi.org/10. 1016/S0891-5849(01)00591-3 PubMed: 11461774.

Atmaca, N., Atmaca, H. T., Kanici, A., \& Anteplioglu, T. (2014). Protective effect of resveratrol on sodium fluoride-induced oxidative stress, hepatotoxicity and neurotoxicity in rats. Food \& Chemical Toxicology, 70, 191-197.

Azab, A. E., Albasha, M. O., Jbireal, J. M., \& Adwas, A. A. (2018). Sodium fluoride induces hepato-renal oxidative stress and pathophysiological changes in experimental animals. Open Journal of Apoptosis, 7(1), 1-23.

Benyettou, I., Kharoubi, O., Hallal, N., Benyettou, H. A., Tair, K., Belmokhtar, M., Ozaslan, M. (2017). Aluminium-induced behavioral changes and oxidative stress in developing rat brain and the possible ameliorating role of Omega6/Omega-3 ratio. Journal of Biological Sciences. https://doi.org/10.3923/jbs. 2017.106.117.

Bishop, N. J., Morley, R., Chir, B., Day, J. P., \& Lucas, A. (1997). Aluminium neurotoxicity in preterm infants receiving intravenous feeding solutions. The New England Journal of Medicine, 336, 1557-1561. 
Blaylock, R. L. (2012). Aluminum induced immunoexcitotoxicity in neurodevelopmental and neurodegenerative disorders. Current Inorganic Chemistry, 2, 000.

Bouaziz, H., Ketata, S., Jammoussi, K., Boudawara, T., Ayedi, F., Ellouze, F., \& Zeghal, N. (2006). Effects of sodium fluoride on hepatic toxicity in adult mice and their suckling pups. Pesticide Biochemistry and Physiology, 86, 124-130.

Bouaziz, H., Amaraa, I. B., Essefia, M., Croute, F., \& Zeghal, N. (2010). Fluorideinduced brain damages in suckling mice. Pesticide Biochemistry and Physiology, 96(1), 24-29.

Bulmer, A. C., Verkade, H. J., \& Wagner, K.-H. (2012). Bilirubin and beyond: a review of lipid status in Gilbert's syndrome and its relevance to cardiovascular disease protection. Progress in lipid research, 52(2),193-205.

Chatterjee, S., Mahapatra, P. S., \& Sarkar, P. (2016). Effect of fluorosis on serum total protein level in a fluoride endemic zone: a cross-sectional observational study. IOSR Journal of Pharmacy, 6(11), 01-04.

Chattopadhyay, A., Podder, S., Agarwal, S., \& Bhattacharya, S. (2011). Fluorideinduced histopathology and synthesis of stress protein in liver and kidney of mice. Archives of Toxicology, 85, 327-335.

Chen, E., Proestou, G., Bourbeau, D., \& Wang, E. (2000). Rapid up-regulation of peptide elongation factor EF-1alpha protein levels is an immediate early event during oxidative stress-induced apoptosis. Experimental Cell Research, 259, 140-148. https://doi.org/10.1006/excr.2000.4952 PubMed: 10942586.

Chinoy, N. J., \& Memon, M. R. (2001). Beneficial effects of some vitamins and calcium on fluoride and aluminium toxicity on gastrocnemius muscle and liver of male mice. Fluoride, 34, 21-33.

Dabrowaska, E., Letko, R., \& Balunowska, M. (2006). Effect of sodium fluoride on the morphological picture of the rat liver exposed to $\mathrm{NaF}$ in drinking water. Advances in Medical Sciences, 51, 91-95.

El-Demerdash, F. M. (2004). Antioxidant effect of vitamin $E$ and selenium on lipid peroxidation, enzyme activities and biochemical parameters in rats exposed to aluminium. Journal of Trace Elements in Medicine and Biology, 18(1), 113-121.

Eraslan, G., Kanbur, M., \& Silici, S. (2007). Evaluation of propolis effects on some biochemical parameters in rats treated with sodium fluoride. Pesticide Biochemistry and Physiology, 88, 273-283.

Fulton, B., \& Jeffery, E. H. (1990). Absorption and retention of aluminium from drinkingwater: effect of citric and ascorbic acids on aluminium tissue levels in rabbits. Fund Appl Toxicol, 14(4), 788-796.

Hamza, R. Z., El-Shenawy, N. S., \& Ismail, H. A. (2015). Protective effects of blackberry and quercetin on sodium fluoride-induced oxidative stress and histological changes in the hepatic, renal, testis and brain tissue of male rat. Journal of Basic and Clinical Physiology and Pharmacology, 26(3), 237-251.

Hassan, H. A., \& Yousef, M. I. (2009). Mitigating effects of antioxidant properties of black berry juice on sodium fluoride induced hepatotoxicity and oxidative stress in rats. Food and Chemical Toxicology, 47, 2332-2337.

He, L., \& Chen, J. (2006). DNA damage, apoptosis and cell cycle changes induced by fluoride in rat oral mucosal cells and hepatocytes. World Journal of Gastroenterology, 12(7), 1144-1148.

Jan, A. T., Azam, M., Siddiqui, K., Ali, A., Choi, I., Mohd, Q., \& Haq, R. (2015). Review: heavy metals and human health: mechanistic insight into toxicity and counter defense system of antioxidants. International Journal of Molecular Sciences, 16, 29592-29630.

Jayatilleke, E., \& Shaw, S. A. (1993). High performance liquid chromatographic assay for reduced and oxidized glutathione in biological samples. Analytical Biochemistry, 214(2), 452-457.

Kanbur, M., Eraslan, G., Silici, S., \& Karabacak, M. (2009). Effects of sodium fluoride exposure on some biochemical parameters in mice: evaluation of the ameliorative effect of royal jelly applications on these parameters. Food and Chemical Toxicology, 47, 1184-1189.

Karatepe, M. (2004). Simultaneous: determination of ascorbic acid and free malonialdehyde in human serum by HPLC-UV. Lcgc North Amerika, 22(4), 362-365.

Kaur, T., Bijarnia, R. K., \& Nehru, B. (2009). Effect of concurrent chronic exposure of fluoride and aluminum on rat brain. Drug and Chemical Toxicology, 32(3), 215-221.

Kinawy, A. A., \& Al-Eidan, A. A. (2018). Impact of prenatal and postnatal treatment of sodium fluoride and aluminum chloride on some hormonal and sensorimotor aspects in rats. Biological Trace Element Research. https://doi org/10.1007/s12011-018-1311-4.

Kinawy, A. A., \& Ezzat, A. R. (2008). Impact of locomotion restraint during the neonatal period on some hormonal and behavioural aspects in male rats. JASMR, 3(2), 205-212.
Kinawy, A. A., \& Ezzat, A. R. (2013). Impact of aluminum and antioxidants on some neural aspects. Riga: Lambert Academic Publishing.

Kojo, S. (2000). Vitamin C: basic metabolism and its function as an index of oxidative stress. Current Medicinal Chemistry, 11, 1041-1064.

Liang, C. H., Li, W. H., Zhang, S. H., Wu, Y. B., Ma, F., Katz, B. P., ... Stookey, G. K. (1999). Analyses of blood chemistry and electrolytes of human exposure to fluoride in drinking water. J Chinese Public Health, 15, 34-36.

Lu, Y., Luo, Q., Cui, H., Deng, H., Kuang, P., Liu, H., ... Zhao, L. (2017). Sodium fluoride causes oxidative stress and apoptosis in the mouse liver. Aging (Albany NY), 9(6), 1623-1639.

Mailloux, R. J., Lemire, J., \& Apana, V. D. (2011). Hepatic response to aluminium toxicity: dyslipidemia and liver diseases. Experimental Cell Research, 317, 22312238.

Michael, M., Barot, V. V., \& Chinoy, N. J. (1996). Investigation of soft tissue functions in fluorotic individuals of north Gujarat. Fluoride, 29, 63-71.

Nabavi, S. F., Habtemariam, S., Jafari, M., Sureda, A., \& Nabavi, S. M. (2012). Protective role of gallic acid on sodium fluoride induced oxidative stress in rat brain. Bulletin of Environmental Contamination and Toxicology, 89, 73-77.

Ozbilgin, K., Boz, T. K., Inan, S., \& Vatansever, S. (2012). RHAMM expression in the rat endometrium during the estrous cycle and following implantation. Journal of Reproduction \& Infertility, 13(3), 131-137.

Patton, C., \& Crouch, S. R. (1977). Enzymatic determination of urea. Analytical Chemistry, 94, 464-496.

Pawłowska-Goral, K., Kurzeja, E., \& Stec, M. (2013). N-acetylcysteine protects against fluoride-induced oxidative damage in primary rat hepatocytes. Toxicology In Vitro, 27(2013), 2279-2282.

Sallam SMA, Nasser MEA, Yousef MSH, El-morsy AM, Mahmoud SAS. (2005)

Tan, H., Liu, K., Zhang, Y., Liu, Y., Lu, C., Yu, D., ... Cui, C. (2011). Effect of fluoride exposure on bone metabolism indicators ALP, BALP, and BGP Yu-e Song. Environmental Health and Preventive Medicine, 16, 158-163.

Trivedi, M. H., Verma, R. J., Sangai, N. P., \& Chinoy, N. J. (2011). Black tea extract mitigation of $\mathrm{NaF}$-induced lipid peroxidation in different regions of mice brain. Fluoride, 44, 243-254.

Viezeliene, D., Jansen, E., Rodovicius, H. H., Kasauskas, A., \& Ivanov, L. (2011). Protective effect of selenium on aluminium-induced oxidative stress in mouse liver in vivo. Environmental Toxicology and Pharmacology, 3(1), 302-306.

Walton, J. R. (2012). Aluminum disruption of calcium homeostasis and signal transduction resembles change that occurs in aging and alzheimer's disease. Journal of Alzheimer's Disease, 29, 255-273.

Wasana, H. M., Perera, G. D., De Gunawardena, P. S., \& Bandara, J. (2015). The impact of aluminum, fluoride, and aluminum-fluoride complexes in drinking water on chronic kidney disease. Environmental Science and Pollution Research International, 22(14), 11001-11009.

Weaver, L. T., Laker, M. F., \& Nelson, R. (1984). Intestinal permeability in the newborn. Archives of Disease in Childhood, 59, 236-241.

Xiong, X. Z., Liua, J. L., Hea, W. H., Xiaa, T., Hea, P., Chena, X. M., ... Wanga, A. G. (2007). Dose-effect relationship between drinking water fluoride levels and damage to liver and kidney functions in children. Environmental Research, $103,112-116$.

Yildirim, S., et al. (2017). An ınvestıgatıon of the protectıve effects of resveratrol on some bıochemıcal parameters and histopathological findıngs in experımentally-ınduced chronıc flurosıs in rats. Fluoride, 50(3), 365-373.

Yildirim, S., et al. (2018). Effect of chronıc exposure to sodıum fluorıde and 7,12dımethylbenz[a]anthracene on some blood parameters and hepatıc, renal, and cardiac histopathology in rats. Fluoride, 51(3), 278-290.

Young, D. S. (1997). Effects of drugs on clinical laboratory tests. Annals of Clinical Biochemistry, 34, 579-581.

Young, D. S. (2001). Effects of disease on clinical laboratory tests, 4th Edition, Vol. 1 and 2. In D.S. Young and R.B. Friedman (Eds). Washington, DC: AACC Press.

Yousef, M. I. (2005). Influence of aluminum chloride and ascorbic acid on performance, digestibility, Caecal microbial activity and biochemical parameters of rabbits. Research Journal of Agriculture and Biological Sciences, 1(1), 10-16.

Zhang, Z., Zhou, B., Wang, H., Wang, F., Song, Y., Liu, S., \& Xi, S. (2014). Maize purple plant pigment protects against fluoride-induced oxidative damage of liver and kidney in rats. International Journal of Environmental Research and Public Health, 11(1), 1020-1033. https://doi.org/10.3390/ijerph110101020.

Zhou, B. H., Zhao, J., Liu, J., Zhang, J. L., Li, J., \& Wang, H. W. (2015). Fluorideinduced oxidative stress is involved in the morphological damage and dysfunction of liver in female mice. Chemosphere, 139, 504-511. 